\title{
Repairing Interlocutor's Mistakes in Selecting Speech Act in Laboratory Classes: A Case Study at Polytechnic Collage in Surakarta, Indonesia
}

\author{
Ratna Susanti $^{1}$, Sumarlam $^{2}$, Djatmika $^{3}$, and Muhammad Rohmadi ${ }^{4}$ \\ \{ratnasusanti@student.uns.ac.id ${ }^{1}$ \} \\ ${ }^{1,2,3}$ Universitas Sebelas Maret, Surakarta, Indonesia
}

\begin{abstract}
The setting in this study was in the pharmacy laboratory of Polytechnic Indonusa Surakarta, Central Java, Indonesia. In the laboratory classes, there are some students who make mistakes and violate procedures. This study aims to repairing interlocutor's mistakes in selecting speech act in an academic situated interaction between student-students of Polytechnic collage, specifically to describe the pragmatic forces and the context following the use of speech acts. The participants were 80 (eighty) students. The study revealed that the pragmatic force on the studied data includes giving information, deciding, commanding, suggesting, challenging, influencing, rebuking, criticizing, and sarcasting. On the observed speech acts, the more indirect utterances were expressed, the stronger pragmatic force on speaking partners. The expressed polite language among the participants in the pharmacy laboratory interaction were realized through the maxim of generosity, agreement and tact maxim. The politeness scale mostly used by the students with fellow mediated by the maxim of sympathy.
\end{abstract}

Keywords: speech acts, interlocutors, mistake, polytecnich collage

\section{INTRODUCTION}

The idea of politeness in language, it at least offers criteria of how one would effectively speak or write with a language that implies polite sense to the addressee. These criteria guide speech participants to create effective and harmonious communication, in addition to avoids them from having misunderstandings, and offend each others. Many experts attempted to explain the criteria for politeness in communication. Goffman, Brown and Levinson, and Leech are among the most leading linguists of politeness theory [1]

The use of language within a language society, generally divided into categories of both politeness and impoliteness. This division will continue to occur in the community as well as the use of other rules. This then raises a perception of whether the language used is either good or not. How is that possible? Pranowo[2]describes several triggering reasons: (1) not everyone understands the rules of politeness, (2) some understand the rules, however, may not as proficient at using politeness rules, (3) some are proficient in using politeness rules in language but not realizing him/herself has really applied the rules of politeness, and (4) some may not 
comprehend the rules of politeness anymore or feeling not proficient in communicating a polite language.

Concerning the interaction process between students and the others, sorts of strategy may need to take into account in a communication. In principle, communication is required to be able to express ideas in humans' social lives, which includes politeness, and language ethics. Politeness is closely related to the use of linguistic elements. Additionally, it closely relates to language feasibility in speech delivered by the speaker to his/her interlocutor(s), while language ethics is closely related to behaviour at the time individuals communicate [3]Languistic politeness concerns the practicing norms observed by certain community. If a community applies the norms and values strictly, then the polite language becomes part of the people's characters. In regard with education, the community who uphold politeness shall internalize it in everyday life process including laboratory classroom interaction.

In regard of the interactional communication in the world of education, i.e., between student and the other students or lecturers and students, of course, they would engage in both verbally and nonverbally communication. In verbal communication, various speeches emerged between speakers and speech partners. Various studies on speech acts of student(s)-the other students have been carried out by previous research. This is shown in several speech act studies based on class interaction as was done by [4], [5],[6], [7], [8], [1], and [9].

Studies on politeness in the context of verbal academic interaction between students and lecturers which focus on caring attitudes has not been widely studied. For this reason, an indepth study of politeness is needed to cope with problems raised between students and lecturers in academic activities on campus through utterance reflecting the indifference in a Sociopragmatic perspective. The following findings report several studies that have also examined the directive politeness strategy. This can be seen from both similarities and differences in the research results.

Among the factors determining a good communication is the presence between speaker(s) and speech partner(s). The speech situation mediating a communication between these parties the so called speech event. Any speech event, is therefore, inseparable from speech acts use that enable speakers communicate intentionally and purposively. Relevant with this article, a language event between lecturers and students communication in practical teaching has caught the researchers' attention. In a teaching contextual situation, it always carries out in an academic reciprocal communication that engages between students-lecturer and student with other fellow students. In this case, the interaction between lecturer(s) and students is determined by speech acts that are strongly influenced by communicative learning activities. In its process, a lecturer has his own way of conveying ideas, knowledge and thoughts to students, much of the communication mediated by the speech acts use that are oriented at creating politeness. In this dimension, politeness principles are needed to maintain good relations between speakers and the speech partners. Leech[10]has formulated the politeness principles into six maxims, namely (1) the maxim of tact, (2) generosity, (3) approbation, (4) modesty, (5) agreement, and (6) the maxim of sympathy.

This study aims to repairing interlocutor's mistakes in selecting speech act in an academic situated interaction between student-students of Polytechnic collage, specifically to describe the pragmatic forces and the context following the use of speech acts; to describe the context following the use of speech acts as a form of politeness in laboratory classes interaction between students and the other students in laboratory activities at the polytechnic campus environment. 


\section{METHOD}

This study used the descriptive-qualitative research approach, it is research paradigm which does not considerstatistical calculation [11]. The data retrieval technique of this study applied note taking technique and content analysis. The data analysis used extra lingual equivalence method. This study was conducted in Polytechnic Indonusa of Surakarta, Central Java, Indonesia. Eighty of both male and female studentswere chosen as the research subjects. The needs of observing students mainly done to explore how those students' act of respondingtheir student(s') interactive utterances and viewed the relationship between the utterances in line with the pragmatic forces beingexericed by the student(s) in the laboratory.

In this study, the researcher(s) attended the target classes and took recording on the students' interaction during the practicing process in laboratory. The researchers used a video recorder assistant to record everything on the interaction which regard to the objectives of the study. Without neglecting the whole class interaction, the recording was focused on the students' speeches recorded during the laboratory classroom observation. In this step, the researchers conducted data reduction tothe utterances beyond the scope of this study.

The data analysis technique in this study was carried out using the pragmatic equivalent method, a method used to study and determine the identity of a particular lingual unit using a determinant beyond the language[12]. Sudaryanto[13]calls this a pragmatic method that centers on speech partner's concern. The data were collected and classified to fit the objectives of this study, the data were then analyzedbased on both intra-lingual and extra-lingual identity technique.

\section{RESULT AND DISCUSSION}

\subsection{An Overview to Language Phenomena of Polytechnic Students}

Polytechnic is one of the vocational higher educational institution that has specificities related to the learning process. The education offers at the Polytechnic is specifically emphasized on developing the ability in applying science and technology practically and are adept at handling work. The characteristics of education at the Polytechnic are as follows: 1) Polytechnic is higher education namely academically based and industrial competence, 2) In the teaching and learning process, theory and practice are held to strengthen mutual reasoning skills and advanced skills mastering in dealing with practical problems with comparisons between theories $30-40 \%$ and practice $60-70 \%$, c) Teaching theory emphasizes the linking of basic concepts with real cases directly through comprehensive problem solving methods, d) teaching practice emphasizes skills integrating theory with practice that produces works or finished products that can be directly used.

Based on the specialization of polytechnics as a vocational campus, a student is required to always think and do creative things to be able to produce advanced products benefited to all community. For this reason, the role of the lecturers involved is not only limited to providing knowledge but also acts as a facilitator, controller, manager, as well as a student source seeker to participate in activities[14], [15]. At present, ideal learning is a learning process leading towards the provision of a larger learner role in the class (learner-centered) so that the dominance of lecturers is much reduced[16]. The lecturers' roles in lecturing process is as an educator, motivator, supervisor, model, and facilitator. Especially with regard to the lecturing 
process, lecturer(s) bear their roles as a facilitator[17];[18]; [16], namely facilitating students to conduct lecture processes that are realized in multiple roles, as a controller, organizer, assessor, prompter, participant, resources, tutors, and observers. Murphey[19]further suggests that the success in academic activity process, whether in class, in the laboratory, or in other spaces depends on the achievement of interaction between lecturers and students. In addition, it is undeniable that every action and expression produced by lecturers in the classroom involves linguistic substances [20]. In this study the authors discussed the use of speech acts between students and the other students in the domain of higher education, especially polytechnic campus students.

Table 1. The Students's Responses Selecting Speech Actthe Interlocutors Mistake

\begin{tabular}{lllllll}
\hline Situation & Dir. & Ass. & Com. & Exp. & Dec. & Total \\
\hline $\begin{array}{l}\text { The class in practicum starts. You see your friend is still } \\
\text { busy operating the cell phone, even though there is } \\
\text { already a prohibition that the cell phone must not be }\end{array}$ & & & & & & \\
active when practicing in the laboratory.
\end{tabular}

According to Table 1, the situational context in the above speech has taken place in the pharmacy laboratory of polytechnic collage in Surakarta. The result of analysis shows that the speech actof directives have higher percentage. There are many sub-directives, such as, asking, ordering, advising, begging, requesting. The discourse completion test/task is a written questionnaire in which a situation is given specifying the setting, the social distance between 
the participants, and their respective social status, followed by a brief dialogue with a blank for the respondent to provide a written response. The subjects are asked to write down what they think they would say in the described situations. This type is called open-ended elicitations. The interrogative sentence, however, impliesa concern for caring to students in orderhe/she be careful at practicing in the laboratory. This circumstance is caused by the laboratory classroom activities which aimed at establishing an attitude of ensuring occupational safety and health.

This section elaborates on the results and findings presented in the previous chapter. To discuss the results of the research, the research question raised earlier in the study will be referred to as follows: how are the students response to other's wrongdoing in training classes? Results of the study showed that the students were almost use directive's speech act than the other speech acts.

The urgency of this research is the phenomenon of the use of language politeness of students who tend to experience irregularities. The result of this research is the form of language politeness that students can use as part of the soft skill supplies in entering the world of work as well as the strengthening of polite character in the academic context. Activity speak is an actual event that someone does in his daily life. In a pragmatics study, the utterance is the smallest unit of verbal interaction that expresses action. All verbal communication involves speech acts. Language will be meaningful when used as a social tool that aims to communicate [21]. In this case, the speech has a relation to the politeness of language because speak is a reflection of politeness in communicating.

\section{CONCLUSION}

Based on the results of data analysis and discussions on the laboratory interaction at the Indonusa Polytechnic of Surakarta, the realized illocutionary acts were: (a) directive (commanding, asking, suggesting,challenging, deciding), (b) assertive (rebuking, criticizing, concluding), c) commisive (opposing), d) expressive (apologizing). The most occurred speech acts were directive speech acts. On the basis of the observed speech acts, the more indirect utterances were expressed, the stronger pragmatic force on speaking partners. Meanwhile the students' expressed polite language with other fellow students in laboratory interaction at the practical classroom were realized through the maxim of generosity, agreement and tact maxim. The politeness scale mostly used by the students with fellow mediated by the maxim of sympathy.

\section{REFERENCES}

[1] R. Susanti, S. Sumarlam, D. Djatmika, and M. Rohmadi, "Responses to Caring Speech Acts: The Politeness Strategies of Indonesian Students in Academic Activities," 2018.

[2] Pranowo, Berbahasa secara Santun. Yogyakarta: Pustaka Pelajar, 2012.

[3] A. Chaer, Kesantunan Berbahasa. Jakarta: Rineka Cipta, 2010.

[4] F. L. Bellack, A. A., Kliebard, H. M., Hyman, R. T. and Smith, The Language of the Classroom. New York: Teachers' College Press., 1966.

[5] C. B. Cazden, Child Language and Education. Oxford, England: Holt, Rinehart \& Winston, 1972.

[6] R. M. Sinclair, J. M., \& Coulthard, Towards an Analysis of Discourse The English Used by Teachers and Pupils. London: London Oxford University Press, 1975.

[7] M. Coulthard, An Introduction to Discourse Analysis. London: Longman, 1985. 
[8] D. de Saint Léger and N. Storch, "Learners' perceptions and attitudes: Implications for willingness to communicate in an L2 classroom," System, 2009.

[9] R. Susanti, S. Sumarlam, D. Djatmika, and M. Rohmadi, "Students-Lecturer(s') Speech Acts in the Academic Practical Teaching Situated-Communication," 3 L Southeast Asian J. English Lang. Stud., vol. In Review, 2019.

[10] G. Leech, The Pragmatics of Politeness. London, New York: Longman Ltd., 2014.

[11] L. J. Moleong, Metode Penelitian Kualitatif. Bandung: Remaja Rosdakarya, 2012.

[12] H. J. Prayitno, A. Ngalim, A. Sutopo, M. Rohmadi, and T. Yuniawan, "POWER, ORIENTATION, AND STRATEGY OF POSITIVE POLITENESS USED BY CHILDREN AT THE AGE OF ELEMENTARY SCHOOL WITH JAVANESE CULTURAL BACKGROUND," Humanus, 2019.

[13] Sudaryanto, Metode dan Aneka Teknik Analisis Bahasa. Yogyakarta: Sanata Dharma University Press, 2015.

[14] T. Bishop, R., \& Glynn, "Addressing power and control issues in educational research," in Culture Counts: Changing power relations in education., 1999.

[15] P. Blatchford, P. Bassett, and P. Brown, "Examining the effect of class size on classroom engagement and teacher-pupil interaction: Differences in relation to pupil prior attainment and primary vs. secondary schools," Learn. Instr., 2011.

[16] Senowarsito, "Politeness Strategies in teacher-student interaction in an EFL classroom context," TEFLIN J., 2013.

[17] J. Harmer, "Book Review : The Practice of English Language Teaching," RELC J., 2007.

[18] W. Littlewood, "Communicative and task-based language teaching in East Asian classrooms," Lang. Teach., 2007.

[19] T. Murphey, "Exploring conversational shadowing," Lang. Teach. Res., 2001.

[20] D. Bloome, S. Power Carter, B. Morton Christian, S. Otto, and N. Shuart-Faris, Discourse analysis \& the study of classroom language \& literacy events-a microethnographic perspective. 2004.

[21] K. Saddhono, "Cultural and social change of foreign students in Indonesia: The influence of Javanese Culture in Teaching Indonesian to Speakers of Other Languages (TISOL)." IOP Conf. Ser.: Ear. and Envi. Sci.. vol. 126 no. 1 IOP Publishing, 2018. 